\section{Calendar of Industrial Pioneetrs.}

December 3, I863. John Watkins Brett died.-A pioneer of submarine telegraphy, Brett obtained permission in 1847 from Louis Philippe to establish connexion by cable between England and France, a project which was first carried out in $185^{\circ}$.

December 4, I804. Philippe Le Bon died.-In France, Le Bon is regarded as the inventor of lighting by gas. Educated for the Government service, in I794 he became a professor in the École des Ponts et Chaussées. Three years later he was able to light his house at Bruchay by the distillation of wood, and in 1799 he was granted a patent. On December 4, 1804 , he was found in the Champs-Elysées murdered by an unknown hand.

December 6, r777. Johann Andreas Cramer died.Regarded as the greatest assayer of his time, Cramer was born in Quedlinburg in I 7ro, taught assaying in Leyden and London, and afterwards was councillor of mines and metallurgy at Blankenburg. His "Docimasia" was published in I736 and his "Elementa Artis Docimasticæ" in 1739.

December 6, I892. Werner von Siemens died.The eldest of the famous Siemens brothers, Werner Siemens was born at Lenthe, Hanover, on December I3, I $8 \mathrm{I} 6$, and in 1838 became an artillery officer. Distinguished for his scientific attainments, with John Georg Halske (I8r4-189o) he founded in 1847 the firm of Siemens and Halske at Berlin, and the following year with Himly laid the first telegraph line in Germany. He made many discoveries in electricity, in I 866 gave half a million marks for the founding of an Imperial Institute of Technology and Physics, and in I888 was ennobled.

December 7, I880. Henry R. Worthington died.The original inventor of the direct-acting steam pump, of which many thousands of various types are manufactured annually, Worthington took out his first patent in $184 \mathrm{I}$, and in 1845 founded the Worthington Hydraulic Works of New York, which became the leading establishment for the construction of steampumping machinery in the United States.

December 7, 1894. Ferdinand Viscomte de Lesseps died.-The originator and constructor of the Suez Canal, one of the great engineering works of last century, de Lesseps was born at Versailles in $180_{5}$, and at the age of twenty joined the French diplomatic service. Among other places he served at Cairo and Alexandria. Obtaining a concession from Said Pasha in 1854 , he started the canal in $185^{8}$; a vessel of 80 tons passed from the Mediterranean to the Red Sea in 1867 , and on November I7, I869, the canal was formally opened. A colossal statue of de Lesseps stands at Port Said. De Lesseps also launched the scheme for the Panama Canal, and when an old man of eighty-eight was with the other directors found guilty of mismanagement and sentenced to a term of imprisonment, which, however, was not enforced.

December 8, r87o. Thomas Brassey died.-At a period when railways were first coming into extensive use, Brassey with various partners carried out some hundreds of important contracts including railways in England, France, Italy, Canada, Australia, Argentine, and India.

December 9, I8I4. Joseph Bramah died.--Known for his invention of a safety lock, a beer engine, the hydraulic press, and a machine for numbering and dating banknotes, Bramah was a native of Yorkshire, but for many years was one of the leading mechanicians in London.

E. C. S.

\section{Societies and Academies.}

\author{
LONDON.
}

Linnean Society, November 2.-Dr. A. Smith Woodward, president, in the chair.-A. B. Rendle: Early specimens of the dahlia and chrysanthemum from the Banksian Herbarium.-J. S. Huxley: The courtship of birds.-B. Daydon Jackson: The use of the name Forstera or Forsteria. Both names were used by Linne on a sheet in his herbarium with his note Fostera vaginalis on a sheet which formerly had a grass-like plant glued upon it and therefore was widely separated from the Stylidiaceous genus which at the present day bears the name Forstera.

Aristotelian Society, November 6.-Prof. A. N. Whitehead, president, in the chair.-A. N. Whitehead: Uniformity and contingency (presidential address). Our awareness of Nature consists of the projection of sense-objects into a spatio-temporal continuum either within or without our bodies. But " projection" implies a sensorium which is the origin of projection. This sensorium is within our bodies, and each senseobject can be described as located in any region of space-time only by reference to a particular simultaneous location of a bodily sensorium. The process of projection consists in our awareness of an irreducible many-termed relation between the sense-object in question, the bodily sensorium, and the space-time continuum, and it also requires our awareness of that continuum as stratified into layers of simultaneity, the temporal thickness of which depends on the specious present. If this account of Nature be accepted, then space-time must be uniform, for any part of it settles the scheme of relations for the whole irrespective of the particular mode in which any other part of it, in the future or the past or elsewhere in space, may exhibit the ingression of sense-objects. Accordingly, the scheme of relations must be exhibited with a systematic uniformity. We have here the primary ground of uniformity in Nature.

Mineralogical Society, November 7 (anniversary meeting).-Dr. A. Hutchinson, president, in the chair.-W. A. Richardson: The frequency-distribution of igneous rocks in relation to petrogenic theories. The distribution of igneous rocks shows a separation into two primary types, probably corresponding to two primary earth shells, which have originated under early planetary conditions. All other rocks are normally distributed about the two primaries, and the probable cause of such a distribution is fractional crystallisation. The frequency-distribution likely to result from different petrogenic processes is examined and discussed.-Miss I. E. Knaggs : The connexion between crystal structure and chemical constitution of carbon compounds. In certain simple substitution products of methane, the crystal symmetry may be predicted from the known configuration of the chemical molecule. The symmetry of a molecule of the type $\mathrm{CX}_{4}$ is that of a regular tetrahedron, $\mathrm{X}$ being either a univalent atom or a group of atoms, which does not destroy the trigonal symmetry about the bonds from the central carbon atom. Compounds of this type crystallise in the cubic system. Compounds in which $\mathrm{X}$ is a more complex group, but sufficiently symmetrical to maintain tetragonal symmetry, crystallise in the tetragonal system, most frequently in the holohedral class, in which case the crystal is considered to be built up of cells each containing eight molecules. Molecules of the type $\mathrm{CX}_{3} \mathrm{Y}$ have one axis of trigonal symmetry, and this symmetry is preserved in the crystal, except when $X$ is hydrogen. The orthorhombic symmetry of molecules of the type $\mathrm{CX}_{2} \mathrm{Y}_{2}$ 